\title{
Cordyceps militaris, The First Record From Family Cordycipitaceae in Turkey
}

\author{
${ }^{*}$ Ilgaz AKATA ${ }^{1}$, Sanlı KABAKTEPE ${ }^{2}$, Hasan AKGÜL ${ }^{3}$ \\ ${ }^{1}$ Ankara University, Faculty of Science, Department of Biology, Ankara, Turkey \\ 2 İnönü University, Battalgazi Vocational School, Battalgazi, Malatya, Turkey \\ ${ }^{3}$ Akdeniz University, Faculty of Science, Department of Biology, Antalya, Turkey \\ Corresponding Author: e-mail: fungus@ hotmail.com.tr
}

Geliş Tarihi: 15.03.2016

Abstract
In the current study, Cordyceps militaris (L.) Fr. was reported for the first time at family level in
Turkey. A short description and figures of the species based on the collected materials are provided.
Keywords: Cordyceps militaris, Cordycipitaceae, New record, Turkey

Cordyceps militaris, Cordycipitaceae Familyası'ndan Türkiye'den İlk Kayıt

Özet

Mevcut çalş̧mada, Cordyceps militaris (L.) Fr. Türkiye'den ilk defa ve familya düzeyinde rapor edilmiştir. Türe ait mantar örneklerinin kısa tanımı ve şekilleri verilmiştir.

Anahtar Kelimeler: Cordyceps militaris, Cordycipitaceae, Yeni kayıt, Türkiye

\section{Introduction}

Cordycipitaceae is a family of the order Hypocreales within the division Ascomycota. Members of the family produce pallid or brightly pigmented and fleshy stromata or subiculum, superficial to completely immersed perithecia, and oriented at right angles to the surface of the stroma, cylindrical asci with thickened apex, cylindrical and multiseptate spores disarticulating into part-spores or remaining intact at maturity (Kirk et al., 2008; Sung et al,, 2007).

Cordyceps is the largest genus of the family and it contains more than 400 species. It is well known as a rare and exotic medicinal genus which has been a highly regarded corner stone of Chinese medicine for centuries. The members of the genus includes a broad range of compounds that are considered nutritional and a various bioactive constituents such as antimicrobial, antiinflammatory, antioxidant, immunomodulatory or antitumor agents have been reported from Cordyceps species (Holliday and Cleaver, 2008; Das et al., 2010).

Cordyceps militaris (L.) Link is the type species of the genus which is an obligatory parasite on larva or pupa of lepidopteran insects (Wang et al., 2008). It is reported many parts of the world, from sub-tropical to temperate regions. C. militaris contains a number of active components such as cordycepin, polysaccharides, ergosterol, and mannitol. Due to its biological and pharmaceutical activities, $C$. militaris has long been known as a one of the most important medicinal fungi (Patel and Ingalhalli, 2013; Reis et al., 2013).

According to the recent checklist (Sesli and Denchev, 2008; et al., 2015) on Turkish macromycota, there are no records for Turkey of members belonging to family Cordycipitaceae.

The aim of the study is to a make contribution to Turkish mycobiota.

\section{Materials and methods}

Fungi samples were collected from İstanbul in $29^{\text {th }}$ December 2015. During field studies, necessary morphological and ecological features of the samples were noted and they were photographed. Thereafter they were taken to the fungarium for necessary macroscopic and microscopic investigations. Identification was performed with the aid of the literature (Breitenbach and Kränzlin, 1984; Hansen and Knudsen, 2000). The identified samples were deposited at Ankara University Herbarium (ANK). 


\section{Results}

Divisio: Ascomycota

Subdivisio: Pezizomycotina

Classis: Sordariomycetes

Subclassis: Hypocreomycetidae

Ordo: Hypocreales

Genus: Cordycipitaceae

Species: Cordyceps militaris (L.) Fr. (1818)

Syn.: Clavaria granulosa Bull.(1791), C. militaris L.(1753), Cordyceps militaris $\mathrm{f}$. alba Kobayasi \& Shimizu ex Y.J. Yao (1995), C. militaris var. sphaerocephala J.C. Schmidt (1817), Corynesphaera militaris (L.) Dumort. (1822), Hypoxylon militare (L.) Mérat (1821), Sphaeria militaris (L.) J.F. Gmel. (1792), Torrubia militaris (L.) Tul. \& C. Tul. (1865), Xylaria militaris (L.) Gray (1821).

\section{Macroscopic and microscopic features}

Stromata club or clavate shaped, divided into fertile and sterile parts (Figure1, 2). Fertile part $10-30 \times 5-12 \mathrm{~mm}$, reddish to dark orange, roughened by ostioles from the orange perithecia (Figure 3). Sterile part 30$40 \times 5-10 \mathrm{~mm}$, yellow, pale o red orange, sometimes motted with orange. Perithecia $550-700 \times 250-400 \mu \mathrm{m}$. broadly ovoid, semi-immersed, Asci 350-400 × 3 4 $\mu \mathrm{m}$, narrowly cylindrical, eight-spored, breaking part into many individual spores (Figure 4). Ascopores filamentous and septate, smooth and hyaline. up to $300 \times 1 \mu \mathrm{m}$, part of spores 3-4 $\times 1 \mu \mathrm{m}$, cylindrical to fusiform (Figure $5)$.

Ecology: Autumn, parasite on larva or pupa of lepidopteran insects (Wang et al., 2008).
Specimen examined: TURKEY-İstanbul: Ataşehir, Kayışdağı, on buried butterfly pupae, among mosses, near pine, $40^{\circ} 57^{\prime} \mathrm{N}$ $29^{\circ} 11^{\prime} \mathrm{E}, 400 \mathrm{~m}, 29.12 .2015$, Akata 6405.

\section{Discussion}

Cordyceps militaris is an entomopathogenic species that parasitizes larva or pupa of lepidopteran insects and grows in mosses, leaf litters or the uppermost soil layer. It is characterized by its production of superficial to completely immersed perithecia on stipitate, clavate, orange to red colored fleshy stromata and ascospores that disarticulate into part-spores at maturity. This is a widespread species and reported in North America, South America, Europe and Asia (Patel and Ingalhalli, 2013; Sung et al., 2007).

C. militaris macroscopically resembles other orange to red-coloured Cordyceps species $(C$. cardinalis and $C$. pseudomilitaris) but it is easily separated from others by being size and morphology of ascospores. Like many Cordyceps species, the ascospores of $C$. cardinalis and $C$. pseudomilitaris do not disarticulate into partspores as do those of $C$. militaris (Sung and Spatafora, 2004).

With the current study, Cordyceps militaris is reported for the first time from Turkey at family level and it will be the first member of Turkish Cordycipitaceae.

\section{Acknowledgements}

Authors would like to thank Ankara University Research Fund (Project no: 15H0430001) for its financial support. Adnan Sinar is also thanked for his valuable help in the field. 


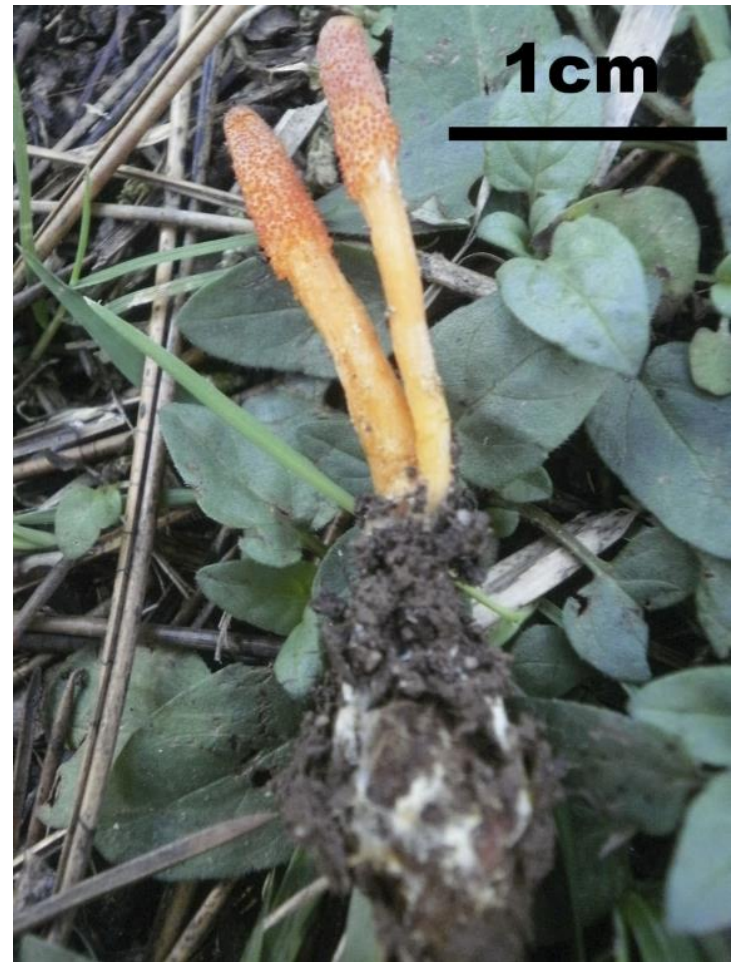

Figure1. Fresh stromata of Cordyceps militaris

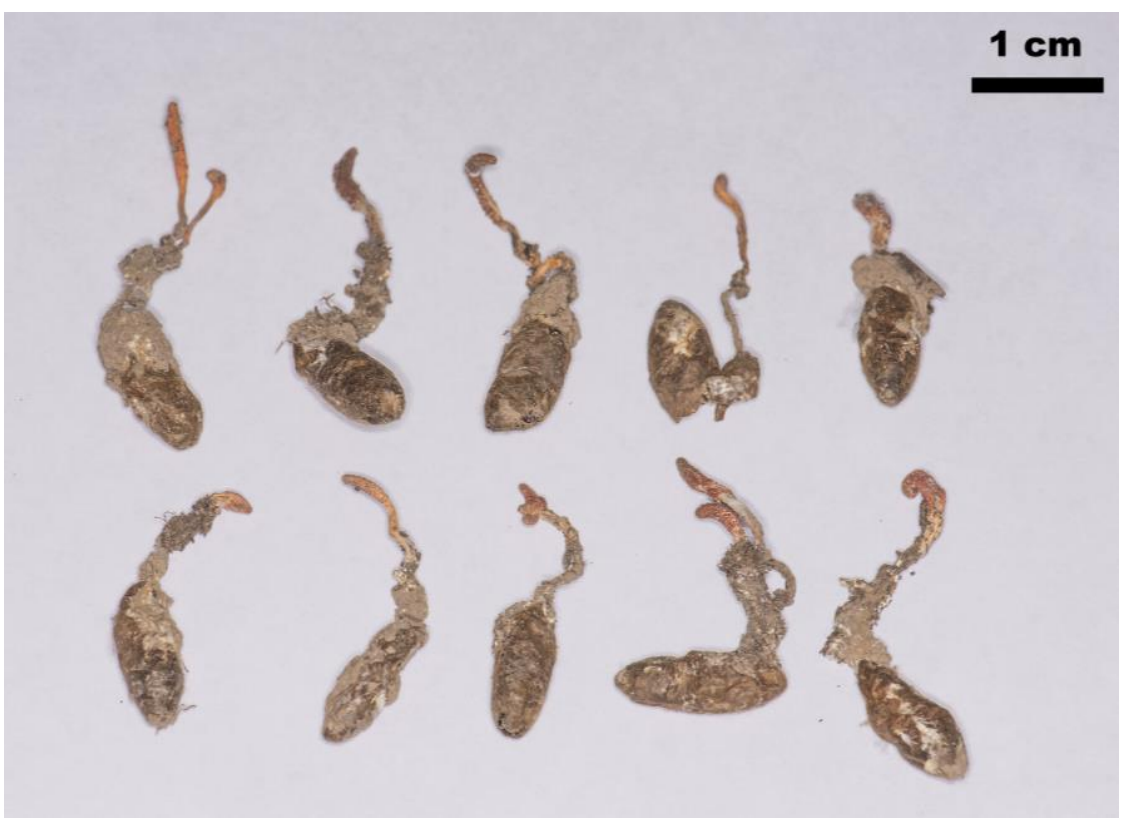

Figure 2. Dry stromata of Cordyceps militaris 


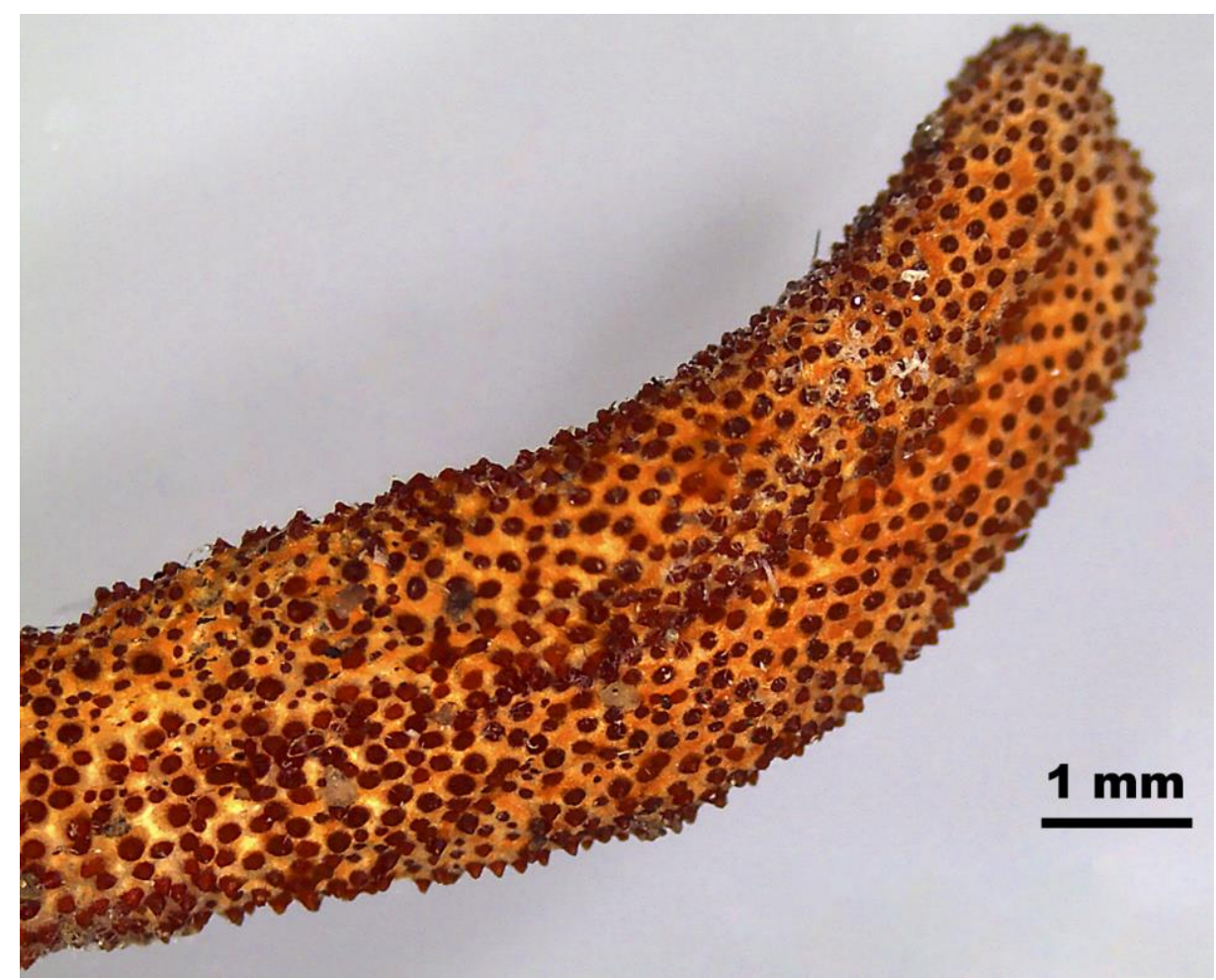

Figure 3. Fertile part of Cordyceps militaris

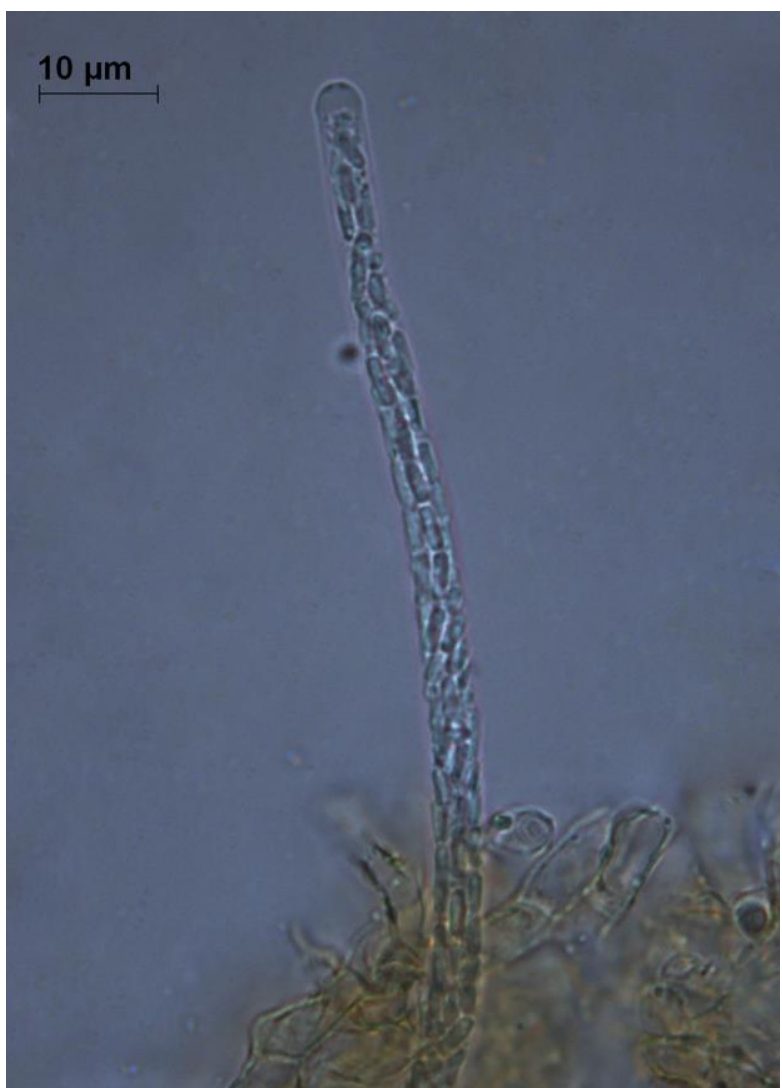

Figure 4. A single ascus of Cordyceps militaris 


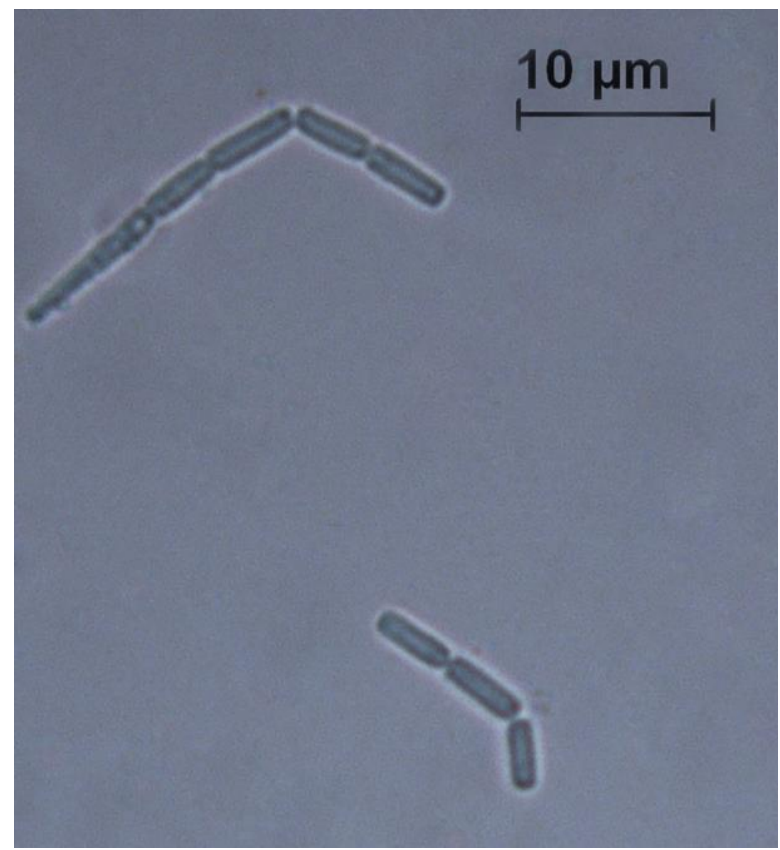

Figure 5. Ascopores of Cordyceps militaris

\section{References}

Breitenbach J., Kränzlin F., 1981. Fungi of Switzerland, Ascomycetes. Verlag Mycologia, 1, Luzern.

Das S. K., Masuda M., Sakurai A., Sakakibara M. 2010. Medicinal uses of the mushroom Cordyceps militaris: current state and prospects. Fitoterapia, 81, 961- 968.

Hansen L., Knudsen H. 2000. Nordic Macromycetes (Ascomycetes), 1, Copehagen: Nordsvamp.

Holliday J., Cleaver M. 2008. Medicinal Value of the Caterpillar Fungi Species of the Genus Cordyceps (Fr.) Link (Ascomycetes). A Review. International Journal of Medicinal Mushrooms, 10(3), 219-234.

Kirk P. F., Cannon, P. F., Minter D. W., Stalpers J. A. 2008. Dictionary of the fungi, 10th ed. CAB International. Wallingford, UK.

Patel K. J., Ingalhalli R. S. 2013. Cordyceps militaris (L.: Fr.) Link - An Important Medicinal Mushroom. Journal of Pharmacognosy and Phytochemistry, 2 (1), 315-319.

Reis F. S., Barros L., Calhelha R. C., Ćirić A., van Griensven L. J., Soković M., Ferreira I. C. 2013. The methanolic extract of Cordyceps militaris (L.) Link fruiting body shows antioxidant, antibacterial, antifungal and antihuman tumor cell lines properties. Food and Chemical Toxicology, 62, 91-98.
Sesli E., Denchev, C.M. 2008. Checklists of the myxomycetes, larger ascomycetes, and larger basidiomycetes in Turkey. - Mycotaxon, 106, 65-67. + [complete version, 1-36, new version uploaded in February 2014].

Solak M. H., Işıloğlu M., Kalmış E., Allı H. 2015. Macrofungi of Turkey, Checklist, 2, Üniversiteliler Ofset, Bornova, İzmir.

Sung G. H, Spatafora J. W. 2004. Cordycepscardinalis sp. nov., a new species of Cordyceps with an east Asian eastern North American distribution. Mycologia, 96(3): 658666.

Sung G. H., Hywel-Jones N. L., Sung J. M., Luangsa-ard J. J., Shrestha B., Spatafora J. W. 2007. Phylogenetic classification of Cordyceps and the clavicipitaceous fungi. Studies in Mycology, 57, 5-59.

Wang L., Zhang W. M., Hu, B., Chen Y. Q., Qu L. H. 2008.Genetic variation of Cordyceps militaris and its allies based on phylogenetic analysis of rDNA ITS sequence data. Fungal Diversity, 31, 147-155. 